\title{
Retinal pigment epithelial cells in epiretinal membranes: an immunohistochemical study
}

\author{
P. S. HISCOTT,' I. GRIERSON,' AND D. McLEOD ${ }^{2}$
}

From the 'Department of Pathology, Institute of Ophthalmology, London, and the ${ }^{2}$ Surgical Vitreoretinal Unit, Moorfields Eye Hospital, London

SUMMARY Immunohistochemical techniques were used to identify cells containing cytokeratins in sections or tissue-culture monolayers from ocular (reference) tissues and also from 22 epiretinal membranes obtained during closed microsurgery for macular pucker or massive preretinal retraction. Results of cytokeratin immunostaining in reference tissues indicated that this is a valuable means of determining the contribution and distribution of epithelial cells in epiretinal membranes, and that the epithelial cells in the membranes were probably derived from the retinal pigment epithelium. Epithelial cells were identified in 17 of the 22 epiretinal membranes, but they did not usually constitute the predominant cell type. We concluded that the fibroblasts or fibroblast-like cells thought to be responsible for the contraction of epiretinal membranes are seldom of retinal pigment epithelial origin. Biomicroscopic pigmentation of a membrane was shown to be a poor guide to its epithelial cell population.

Epiretinal membranes (ERMs) are cellular proliferations on the retinal surface which sometimes complicate the natural history or surgical treatment of rhegmatogenous retinal detachment. Contraction of an ERM localised to the posterior retina produces macular pucker, while more widespread ERM contraction causes massive preretinal retraction (MPR) or proliferative vitreoretinopathy. Retinal pigment epithelial (RPE) cells have been implicated as major contributors to such proliferations and as progenitors of the fibroblasts or fibroblast-like cells responsible for membrane contraction. ${ }^{1-5}$

Histopathological analysis has suggested that metaplastic cells derived from a variety of sources may be present in ERMs, ${ }^{4-11}$ but morphological and ultrastructural criteria are an unreliable means of demonstrating the precise origins of component cells. Tissue culture and immunohistochemical techniques have recently been employed to elucidate further their cellular derivation, ${ }^{12-15}$ but so far only the glial cell contribution to ERMs has been comprehensively investigated. ${ }^{15}$ In view of the possible importance of RPE cells in the pathophysiology of ERMs, we have used immunohistochemical markers to two of the

Correspondence to Dr Ian Grierson, Pathology Department, Institute of Ophthalmology, 17/25 Cayton Strect, London EC1V 9AT. cytoskeletal proteins of epithelial cells-prekeratin and keratin-to demonstrate the contribution and distribution of epithelial cells in ERMs. Sections of surgically excised ERMs, together with cells derived from ERMs in tissue culture, were investigated following closed intraocular microsurgery for macular pucker and MPR mainly complicating rhegmatogenous retinal detachment.

\section{Material and methods}

STANDARDS

To confirm the specificity of immunostaining within the ERMs, and to provide intensity standards for each immunohistochemical procedure, a variety of tissues (Table 1) and tissue culture monolayers (Table 2) were assessed for prekeratin and keratin content. These materials were derived from section or dissection of the following globes: 4 adult albino rabbit eyes, 2 bovine eyes, 2 adult owl monkey eyes, an albino human eye ( 20 weeks gestation), and 3 adult human eyebank globes. In addition 4 human eyes containing retinal detachments were studied.

\section{EPIRETINAL MEMBRANES}

Excised ERMs were obtained from 22 eyes undergoing closed intraocular microsurgery for macular 
Table 1 Tissue standards for immunohistochemical staining

\begin{tabular}{|c|c|c|c|}
\hline & \multirow[b]{2}{*}{$F / P$} & \multicolumn{2}{|c|}{$\begin{array}{l}\text { Intensity of } \\
\text { immunostaining }\end{array}$} \\
\hline & & Prekeratin & Keratin \\
\hline \multicolumn{4}{|l|}{ Corneal epithelium } \\
\hline Adult albino rabbit & $F \& P$ & +++ & NP \\
\hline Adult bovine & $\mathbf{F}$ & +++ & +++ \\
\hline Adult owl monkey & $\mathbf{P}$ & +++ & +++ \\
\hline Fetal albino human & $\mathbf{P}$ & +++ & +++ \\
\hline \multicolumn{3}{|l|}{ Corneal endothelium } & +++ \\
\hline Adult albino rabbit & $F \& P$ & + & NP \\
\hline Adult bovine & $\mathrm{F}$ & - & - \\
\hline Adult owl monkey & $\mathbf{P}$ & - & $+1-$ \\
\hline Fetal albino human & $P$ & - & - \\
\hline $\begin{array}{l}\text { Adult human } \\
\text { Lens epithelium }\end{array}$ & $F \& P$ & Lens epithelium & $+1-$ \\
\hline Adult albino rabbit & $\mathrm{F} \& \mathrm{P}$ & $+1-$ & NP \\
\hline Adult owl monkey & $\mathbf{P}$ & - & - \\
\hline Fetal albino human & $\mathbf{P}$ & - & - \\
\hline \multicolumn{4}{|l|}{ Iris epithelium } \\
\hline Adult albino rabbit & $F \& P$ & $+1-$ & NP \\
\hline Fetal albino human & & + & + \\
\hline \multicolumn{4}{|l|}{ Ciliary epithelium } \\
\hline Adult albino rabbit & $\mathrm{F} \& \mathrm{P}$ & - & NP \\
\hline Adult human & $\mathrm{F} \& \mathrm{P}$ & - & - \\
\hline \multicolumn{4}{|l|}{ Neuroretinal tissue } \\
\hline Adult owl monkey & $\mathbf{P}$ & - & - \\
\hline Fetal albino human & $\mathbf{P}$ & - & - \\
\hline \multicolumn{4}{|l|}{ Retinal pigment epithelium } \\
\hline Adult albino rabbit & $F \& P$ & + & NP \\
\hline Fetal albino human & $\mathbf{P}$ & + & + \\
\hline Adult human & $F \& P$ & + & + \\
\hline Metaplastic adult human & $\mathbf{P}$ & ++ & ++ \\
\hline
\end{tabular}

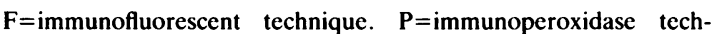
nique. $\mathrm{NP}=$ not performed.

pucker (14 eyes) or MPR ( 8 eyes); aetiological factors and clinical circumstances surrounding the surgery were recorded. A standard proforma documenting the biomicroscopic features of each membrane was also completed by the surgeon; in this investigation particular attention was paid to the presence or absence of visible pigmentation in the ERM prior to its removal from the retinal surface.

Sixteen of the peeled ERMs were embedded directly for histopathological and immunohistochemical analysis (Table 3 ). Monolayers of cells were grown in tissue culture from the remaining 6 ERMs by a method previously described, ${ }^{14}$ (Table 4 ). Only ERMs with a prominent cellular component (as distinct from late collagenous scars) were included in this study.

SPECIMEN PREPARATION

Eyes and epiretinal membranes. Globes to be used as
Table 2 Tissue culture standards for immunohistochemical staining

\begin{tabular}{|c|c|c|c|}
\hline & \multirow[b]{2}{*}{$F / P$} & \multicolumn{2}{|c|}{$\begin{array}{l}\text { Intensity of } \\
\text { immunostaining }\end{array}$} \\
\hline & & Prekeratin & Keratin \\
\hline \multirow{4}{*}{$\begin{array}{l}\text { Bovine corneal epithelium } \\
\text { Human lens epithelium } \\
\text { Bovine retinal pigment } \\
\text { epithelium } \\
\text { Human retinal pigment } \\
\text { epithelium }\end{array}$} & $F$ & +++ & +++ \\
\hline & F & NP & + \\
\hline & F & ++ & + \\
\hline & $F \& P$ & ++ & ++ \\
\hline
\end{tabular}

$\mathrm{F}=$ immunofluorescent technique. $\mathrm{P}=$ immunoperoxidase technique. $\mathrm{NP}=$ not performed.

standards and eight of the ERMs were fixed in 10\% formol-saline, dehydrated in graded alcohols and embedded in paraffin wax. In an attempt to enhance visualisation of immunostaining, globes containing heavily pigmented tissues were bleached by various bleaching methods. Of these, only $0 \cdot 25 \%$ potassium permanganate followed by oxalic acid preserved tissue integrity and produced effective bleaching. Portions of bovine cornea and the remaining eight ERMs were placed in OCT embedding media (LabTek Products, Illinois) and immediately frozen in liquid nitrogen. At least four wax or frozen sections from each tissue were then prepared for immunoperoxidase or immunofluorescent staining as previously described. ${ }^{15}$ Sections were also taken for conventional (haematoxylin and eosin) staining.

Tissue culture monolayers. Monolayers to be used as reference standards and primary monolayers growing from ERM explants were thoroughly washed in phosphate-buffered saline (PBS, $\mathrm{pH} \mathrm{7 \cdot 6)}$ to remove culture medium. They were then air-dried for 20 minutes before immunohistochemical staining.

\section{IMMUNOHISTOCHEMISTRY FOR KERATINS}

Cytokeratins differ both biochemically and immunologically between various epithelia, ${ }^{16-18}$ so we used two different antibodies, each with a wide spectrum of reactivity, in order to minimise false-negative staining: (a) antiprekeratin (Miles Scientific; Slough, England) raised in guinea-pigs with fetal bovine hoof and diluted between 1:10 and 1:50 in TRIS-buffered saline (TBS, pH 7.6). (b) antikeratin (Dako Corp., California, USA) raised in rabbits with human stratum corneum from the foot and diluted between 1:30 and $1: 200$ in TBS.

Immunoperoxidase demonstration of prekeratin was conducted by a standard indirect peroxidase technique as outlined by Mukai and Rosai. ${ }^{19}$ For keratin, immunoperoxidase staining was achieved with a peroxidase-antiperoxidase method previously 


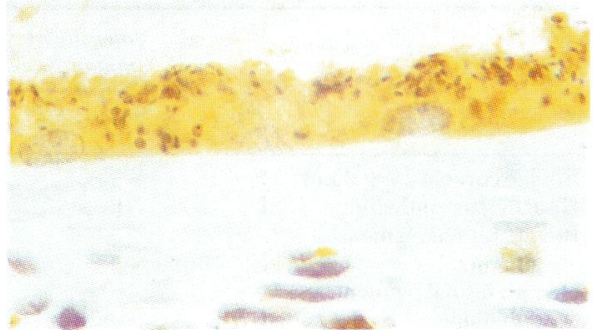

Fig. 1a

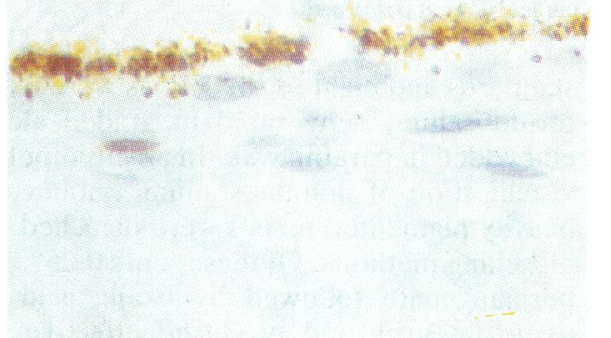

Fig. 1b

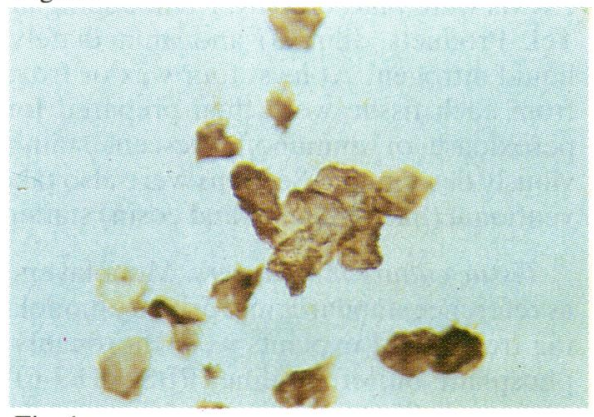

Fig. 1c

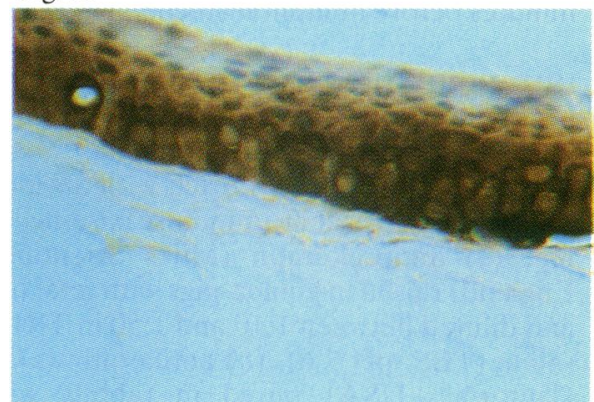

Fig. 1d

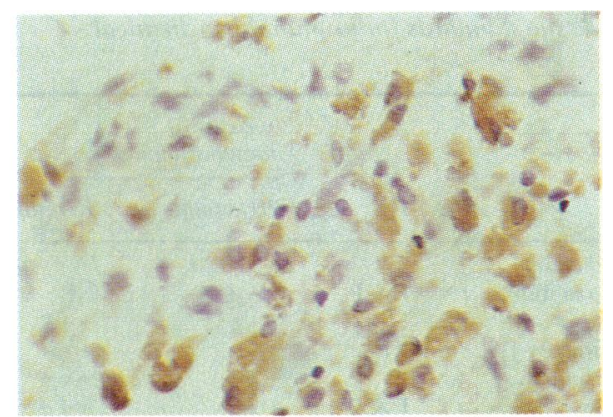

Fig. 1e

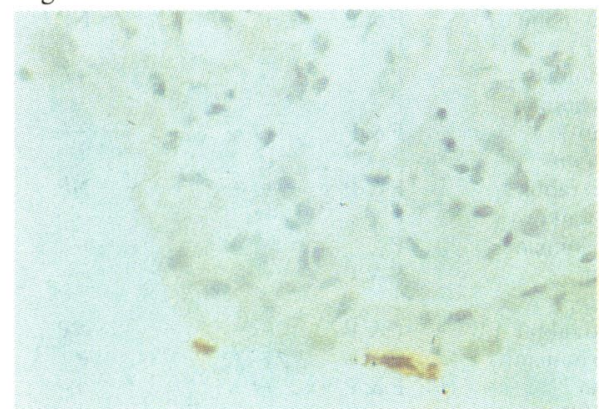

Fig. 1f

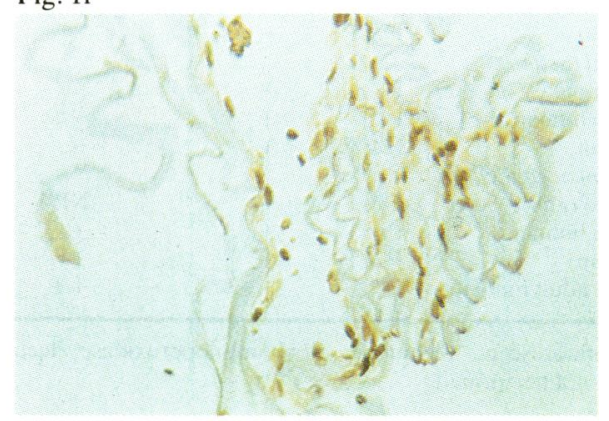

Fig. 1g

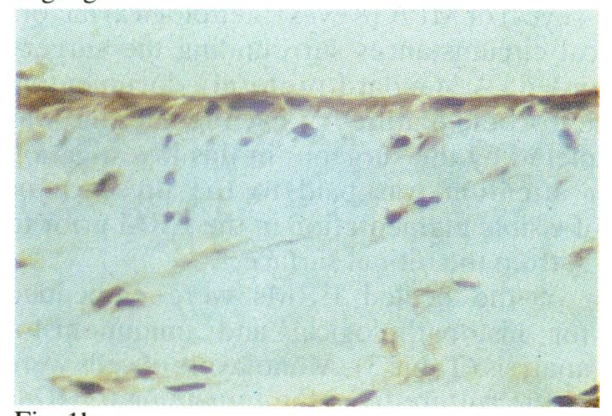

Fig. 1h 


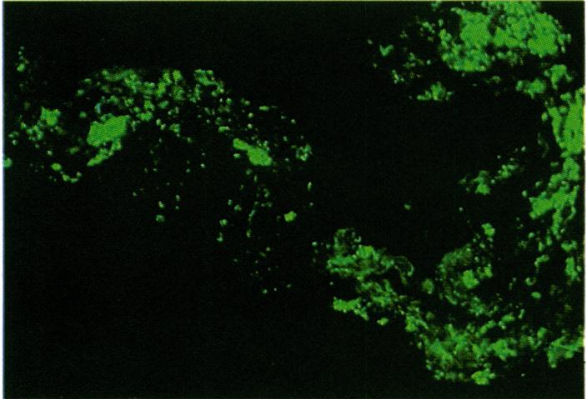

Fig. 2a

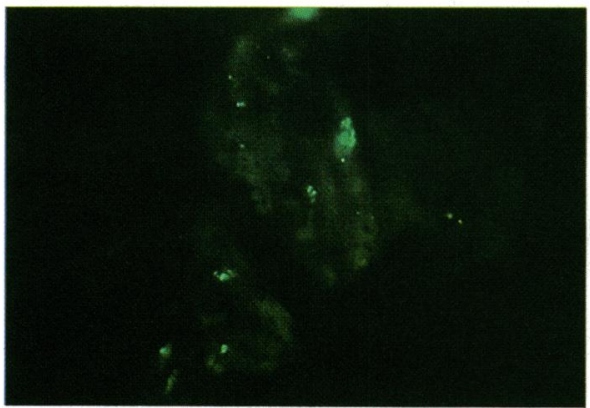

Fig. 2b

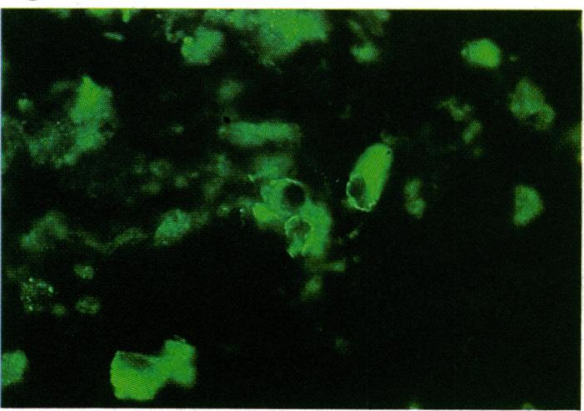

Fig. 2c

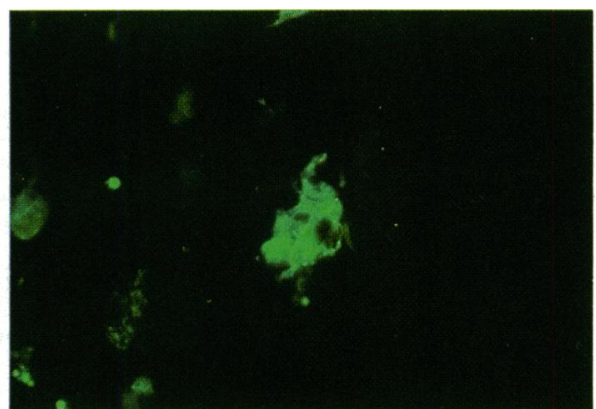

Fig. 2d

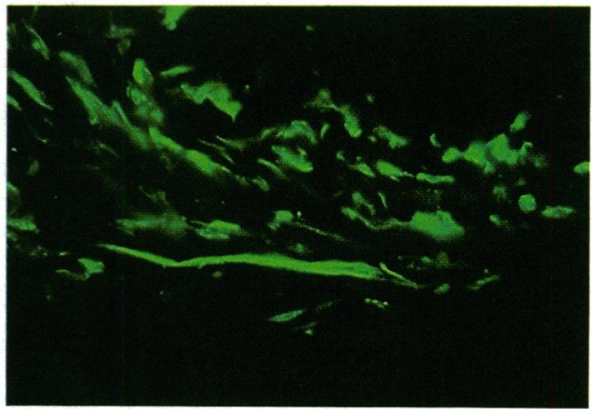

Fig. 2e

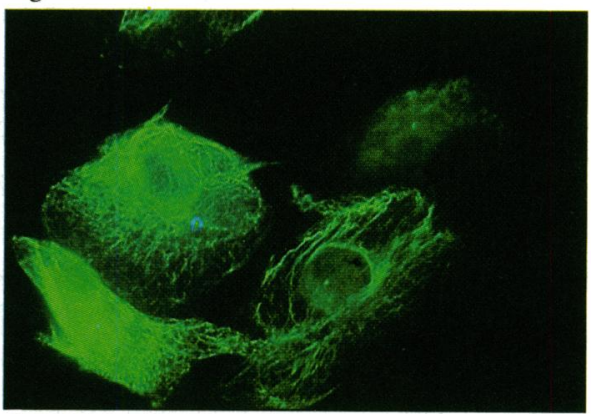

Fig. $2 f$

Fig. 2 Immunofluorescent staining for prekeratin and keratin in frozen sections and cell monolayers. ( $\mathrm{a}$ and $\mathrm{b})$ Frozen sections from two ERMs stained for prekeratin; in (a) epithelial cells abound, whereas in (b) epithelial cells are rare $(\times 130)$. (c and d) Frozen sections from two ERMs stained for keratin; in (c) epithelial cells are prominent, exhibiting either moderate or intense fluorescence, whereas in (d) only a small focus of positively staining cells can be identified (×530). (e) Frozen section from an ERM stained for prekeratin; note the elongated spindle shape of one of the positively staining cells $(\times 530)$. (f) Monolayer growing from an ERM in tissue culture stained for keratin; the epithelial cells have positive cytoplasmic and negative nuclear fluorescence; note the filamentous arrangement of the cytokeratins $(\times 660)$. 
Table 3 Immunohistochemistry of 16 embedded peeled epiretinal membranes

\begin{tabular}{|c|c|c|c|c|c|c|c|c|c|}
\hline No. & $\begin{array}{l}M P / \\
M P R\end{array}$ & Aetiology & $\begin{array}{l}\text { Biomicroscopic } \\
\text { pigmentation }\end{array}$ & $F / P$ & $\begin{array}{l}\% \text { cells } \\
\text { prekeratin } \\
\text { positive }\end{array}$ & $\begin{array}{l}\% \text { cells } \\
\text { keratin } \\
\text { positive }\end{array}$ & $\begin{array}{l}\text { Intensity } \\
\text { prekeratin } \\
\text { staining }\end{array}$ & $\begin{array}{l}\text { Intensity } \\
\text { keratin } \\
\text { staining }\end{array}$ & $\begin{array}{l}\text { Distribution } \\
\text { of epithelial } \\
\text { cell } \\
\text { component }\end{array}$ \\
\hline 1 & MP & $\begin{array}{l}\text { Multiple surgery for large tear and RRD; } \\
\text { postop. uveitis }\end{array}$ & Non-pigmented & $\mathbf{P}$ & $90 \%$ & $90 \%$ & ++ & ++ & Focus/diffuse \\
\hline 2 & MP & $\begin{array}{l}\text { Surgery for multiple large breaks and } \\
\text { RRD; }\end{array}$ & Non-pigmented & $P$ & $60 \%$ & $40 \%$ & ++ & ++ & $\begin{array}{l}\text { Focus/layer/ } \\
\text { diffuse }\end{array}$ \\
\hline 3 & MP & $\begin{array}{l}\text { Multiple surgery for multiple breaks and } \\
\text { RRD; vitreous haemorrhage }\end{array}$ & Pigmented & $\mathbf{F}$ & $40 \%$ & $40 \%$ & ++ & +++ & Layer/diffuse \\
\hline 4 & MP & $\begin{array}{l}\text { Surgery for multiple tears and RRD; post- } \\
\text { op. vitreous haemorrhage }\end{array}$ & Non-pigmented & $\mathrm{P}$ & $25 \%$ & $10 \%$ & ++ & + & Diffuse \\
\hline 5 & MP & $\begin{array}{l}\text { Vitreous haemorrhage after blunt trauma; } \\
\text { no retinal breaks }\end{array}$ & Non-pigmented & $\mathrm{P}$ & $25 \%$ & $20 \%$ & ++ & ++ & Diffusc \\
\hline 6 & MP & $\begin{array}{l}\text { Silicone oil exchange for recurrent RRD; } \\
\text { later peel under oil }\end{array}$ & Non-pigmented & $\mathrm{F}$ & $20 \%$ & $20 \%$ & ++ & ++ & Focus \\
\hline 7 & MP & $\begin{array}{l}\text { Posterior penetrating injury; retinal } \\
\text { incarceration and vitreous haemorrhage }\end{array}$ & Non-pigmented & $\mathrm{F}$ & $10 \%$ & NP & + & NP & Diffuse \\
\hline 8 & MP & $\begin{array}{l}\text { Multiple surgery for posterior penetrating } \\
\text { injury and RRD; retinal incarceration }\end{array}$ & Pigmented & $\mathrm{F}$ & $5 \%$ & NP & + & NP & Diffuse \\
\hline 9 & MP & $\begin{array}{l}\text { Silicone oil exchange for giant tear and } \\
\text { total RRD; later peel under oil }\end{array}$ & Non-pigmented & $\mathbf{P}$ & $0 \%$ & $0 \%$ & & & \\
\hline 10 & MP & $\begin{array}{l}\text { Central retinal vein occlusion and vitreous } \\
\text { haemorrhage }\end{array}$ & Pigmented & $F$ & $0 \%$ & $0 \%$ & & & \\
\hline 11 & MPR & $\begin{array}{l}\text { Surgery for aphakic RRD; postop. } \\
\text { vitreous haemorrhagc }\end{array}$ & Pigmented & $\mathbf{F}$ & $50 \%$ & $50 \%$ & ++ & +++ & Focus/diffuse \\
\hline 12 & MPR & $\begin{array}{l}\text { Surgery for large break and RRD in high } \\
\text { myopia }\end{array}$ & Pigmented & $\mathbf{P}$ & $20 \%$ & $20 \%$ & + & ++ & Focus/diffuse \\
\hline 13 & MPR & $\begin{array}{l}\text { Acute retinal necrosis syndrome; multiple } \\
\text { breaks and RRD }\end{array}$ & Non-pigmented & $P$ & $15 \%$ & $10 \%$ & ++ & ++ & Diffuse \\
\hline 14 & MPR & $\begin{array}{l}\text { Surgery for multiple posterior breaks } \\
\text { and RRD }\end{array}$ & Pigmented & $\mathbf{F}$ & $10 \%$ & $10 \%$ & ++ & + & Focus/diffuse \\
\hline 15 & MPR & $\begin{array}{l}\text { Multiple surgery for multiple breaks and } \\
\text { RRD }\end{array}$ & Non-pigmented & $\mathrm{P}$ & $0 \%$ & $0 \%$ & & & \\
\hline 16 & MPR & $\begin{array}{l}\text { Multiple surgery for aphakic RRD with } \\
\text { vitreous haemorrhage and } \\
\text { endophthalmitis }\end{array}$ & Non-pigmented & $\mathrm{F}$ & $0 \%$ & $0 \%$ & & & \\
\hline
\end{tabular}

$\mathrm{MP}=$ macular pucker. $\mathrm{RRD}=$ rhegmatogenous retinal detachment $\mathrm{MPR}=$ massive preretinal retraction. $\mathrm{NP}=$ not performed. $\mathrm{P}=$ immunoperoxidase technique. $F=$ immunofluorescent technique.

described. ${ }^{15}$ To highlight immunostaining in pigmented tissues we employed two staining substrates yielding different coloured reaction products: 3,3 diaminobenzidine tetrahydrochloride (DAB) or 3amino-9-ethylcarbazole (AEC), which gave brown and pink reaction products respectively. Immuno- fluorescent staining for both prekeratin and keratin on sections and cell monolayers was performed by the indirect immunofluorescent technique previously employed. ${ }^{145}$ Control sections or monolayers were processed in each immunostaining procedure with omission or substitution of the primary antibody.

Table 4 Immunofluorescence of six tissue culture monolayers from peeled epiretinal membranes

\begin{tabular}{|c|c|c|c|c|c|c|}
\hline \multicolumn{2}{|c|}{$\begin{array}{l}\text { No. } M P / \\
\qquad M P R\end{array}$} & Aetiology & $\begin{array}{l}\text { Biomicroscopic } \\
\text { pigmentation }\end{array}$ & $\begin{array}{l}\% \text { cells } \\
\text { positive }\end{array}$ & $\begin{array}{l}\text { Intensity } \\
\text { of prekeratin } \\
\text { staining }\end{array}$ & $\begin{array}{l}\text { Intensity of } \\
\text { keratin } \\
\text { staining }\end{array}$ \\
\hline 1 & MP & Multiple surgery for large tear and RRD & Non-pigmented & $25 \%$ & NP & ++ \\
\hline 2 & MP & Multiple surgery for large dialysis and RRD after blunt trauma & Pigmented & $10 \%$ & NP & ++ \\
\hline 3 & MP & $\begin{array}{l}\text { 'Idiopathic' epimacular membrane and peripheral retinoschisis } \\
\text { without breaks }\end{array}$ & Non-pigmented & $10 \%$ & ++ & +++ \\
\hline 4 & MP & Extensive cryotherapy for small flat horseshoe tear & Non-pigmented & $0 \%$ & & \\
\hline 5 & MPR & Silicone oil exchange for giant tear and RRD; later peel under oil & Pigmented & $50 \%$ & ++ & +++ \\
\hline 6 & MPR & $\begin{array}{l}\text { Multiple surgery for dialysis and RRD after blunt trauma; retinal } \\
\text { incarceration }\end{array}$ & Non-pigmented & $50 \%$ & +++ & ++ \\
\hline
\end{tabular}

$M P=$ macular pucker. $R R D=$ rhegmatogenous retinal detachment. $M P R=$ massive preretinal retraction. $N P=$ not performed. 
Using 'in situ' and cultured corneal epithelium as reference standards for prekeratin and keratin labelling, we evaluated staining of the various tissues and cultured monolayers taking into account the antibody dilution at which the tissue or cells stained. For both immunoperoxidase staining (' $P$ ' in Tables 1,2 , and 3) and immunofluorescence (' $F$ ' in Tables 1, 2, 3, and 4), intensity of staining was assessed as follows:

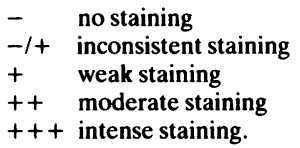

If intensity of staining varied between cells within a specimen, the mean result was recorded. In the peeled ERMs or their monolayers the percentage of cells staining positively for prekeratin or keratin was also recorded. These semiquantitative assessments were made by two observers (P.S.H. and I.G.) independently and subsequently averaged.

\section{Results}

\section{STANDARDS}

RPE cells in situ stained positively for cytokeratins (Table 1; Figs. 1a, b): the staining patterns for keratin and prekeratin were similar but more consistent results were obtained with the prekeratin marker. Metaplastic RPE cells beneath detached human retina and bovine and human RPE cells in vitro showed more impressive (moderate) staining for keratins than did normal RPE cells (Tables 1 and 2; Fig. 1c). The only cells to show intense staining for the cytokeratin markers, either in the globes or in tissue culture, were corneal epithelial cells (Tables 1 and 2; Fig. 1d). All the other cells examined were either weakly positive, negative, or variable in staining pattern (Tables 1 and 2).

\section{EMBEDDED ERMS}

Twelve of the 16 embedded ERM-specimens contained epithelial cells as shown by immunohistochemical staining for keratin and prekeratin (Figs. 1e-h;2a-e). The estimated epithelial cell contribution in the ERMs ranged from approximately $90 \%$ to $5 \%$ (Table 3). In the majority of ERMS, however, only $25 \%$ or less of the cells were positively staining for prekeratin and keratin, and only one specimen had a predominant epithelial cell component.

In most ERMs equal numbers of cells stained for prekeratin and for keratin; in four ERMs, however, cells staining for prekeratin outnumbered cells staining for keratin (Table 3). Overall the intensity of prekeratin staining parallelled that of keratin, and with both antibodies some variation in staining in- tensity was observed between cells in individual specimens (Fig. 2c).

The distribution of epithelial cells within the 12 positively staining ERMs was variable, but three patterns (diffuse, foci, and layers) were recognised occurring either singly or in combination (Table 3 ). Foci were defined as circumscribed aggregates of cells (Fig. 2d) and were present in six of the 12 ERMs. A layer of cells forming a single lamina on a surface of the ERM occurred in two specimens (Fig. 1h). In 11 ERMs, however, isolated cells scattered throughout the membrane were recognised (Figs. 1e, g; 2a, c). Irrespective of their pattern of distribution the epithelial cells usually had a cuboidal or oval shape (Figs. 1h, 2c); the remainder of the positively staining cells looked like fibroblasts, that is, they were either kite-shaped or spindle-shaped (Figs. 1g, 2e). However, such fibroblast-like epithelial cells were present in only four ERMs, and the great majority of fibroblast-like cells were negatively staining. In only one membrane did fibroblast-shaped epithelial cells predominate (Fig. 1g; specimen 1 in Table 3 ).

MONOLAYERS FROM ERMS

Five of the six tissue culture monolayers growing from ERM explants contained cells which stained positively for cytokeratins, sometimes in substantial numbers (Table 4). The proportions of cells fluorescing after antiprekeratin and antikeratin preparation were judged to be equal in each monolayer (as shown in a single column in Table 4). However, these results may not represent the proportion of epithelial cells in the ERM explant because the culture medium may selectively enhance or repress the growth of individual cell types. As in pure monolayers of RPE cells, the melanin content of staining cells decreased with progressive cell division in culture and the staining intensity for epithelial markers was more pronounced than that seen in RPE cells in situ. The positively staining cells grown from ERMs adopted a flattened oval shape and showed a bright filamentous pattern in their cytoplasm which was particularly strong around the nucleus (Fig. 2f). The negatively staining cells in the monolayers had the morphological and locomotory characteristics of inflammatory cells, glial cells, and/or fibroblasts.

CLINICO-IMMUNOHISTOCHEMICAL CORRELATION The presence of clinically recognisable pigmentation in an ERM (eight specimens in Tables 3 and 4) correlated well with subsequent immunohistochemical demonstration of an epithelial cell component in the embedded ERM or tissue culture monolayer. The only exception (specimen 10 in Table 3) was a pigmented ERM removed during microsurgery for a vitreous haemorrhage in which haemosiderin laden 
macrophages were responsible for the ERM pigmentation. Conversely, the absence of biomicroscopically apparent pigmentation in an ERM provided no clue to the epithelial cell content; 10 of the 14 non-pigmented membranes had a significant epithelial cell component (Tables 3 and 4), and the embedded ERM with the greatest proportion of positively staining cells (specimen 1 in Table 3 ) was clinically non-pigmented. Identification of the reasons for the presence or absence of biomicroscopic pigmentation in an ERM was attempted. Most melanin-containing cells were positive for epithelial markers, but not all. Substantial numbers of cells without melanin in their cytoplasm were positively staining, and extracellular melanin granules were abundant in some specimens. Thus such factors as incorporation of melanin by non-epithelial cells, progressive melanin-loss from RPE cells after each cell division, cocooning of cells in collagen and clumping of melanin-containing cells all tend to make biomicroscopic estimation of pigmentation a poor guide to epithelial cell content in ERMs. Our histochemical estimates of epithelial cell contribution in ERMs showed that those classified as 'pigmented' had on average a $21 \%$ epithelial cell content, whereas nonpigmented ERMs were not dissimilar with a $22 \%$ epithelial cell content.

Overall, epimacular membranes removed from eyes with traction detachment localised to the posterior pole (MP) contained a somewhat greater proportion of epithelial cells than did ERMs peeled from bullously elevated immobile retina (MPR) (Table 3). Fourteen of the 17 ERMs with an epithelial cell component in sections or monolayers were removed from eyes with a history of (or in the presence of) a rhegmatogenous retinal detachment (Tables 3 and 4). Of the remaining three ERMs which contained or grew positively staining cells two (specimen 5 in Table 3; specimen 3 in Table 4) were obtained from eyes with no clinically identified retinal break, and the origin of this epithelial cell component is therefore obscure. Four of the five ERMs with no positively staining cells in sections or monolayers were removed from eyes which contained a retinal break (Tables 3 and 4), so the presence of exposed RPE cells on Bruch's membrane did not necessarily ensure an epithelial cell component in the associated ERM.

\section{Discussion}

When RPE cells are implanted into the vitreous cavity of rabbits and monkeys, their morphology changes so they may no longer resemble RPE cells 'in situ. ${ }^{20} 21$ Human RPE cells can similarly change in their appearance if they are displaced on to the retinal surface, ${ }^{5}$ with consequent difficulties in cell identifica- tion in ERMs and potential confusion with fibrous astrocytes. ${ }^{8}$ Conversely, the cytokeratins of epithelial cells are retained in long-term tissue culture and during neoplastic transformation ${ }^{22-26}$ and frequently become more prominent-for example, keratin synthesis demonstrated during squamous metaplasia of RPE cells in organ culture. ${ }^{27}$ We have shown that, both in tissue culture and during metaplasia in the subretinal space, RPE cells stain more intensely for cytokeratins than normally despite their altered morphology. Thus, while the reliability of the ultrastructural criteria which can be used to identify RPE cells decreases with cellular transformation, the reliability of immunohistochemical identification may well increase. Furthermore, light microscopic immunohistochemistry on multiple sections of ERM specimens permits more representative tissue sampling for analysis compared with electron microscopy. For these reasons we consider immunostaining to be a powerful technique in the elucidation of the contribution and distribution of epithelial cells in ERMs.

Apart from penetrating injuries, the clinical circumstances surrounding the development of ERMs suggest a limited number of sources from which epithelial cells could gain access to the retinal surface. Because of the well established association of retinal break formation, RPE cell dispersion into the vitreous cavity, and development of ERMs, it appears likely that most epithelial cells in ERMs would be of RPE cell origin. Furthermore, of all the intraocular epithelia 'in situ' in our study, RPE cells stained for keratins the most consistently (albeit weakly), and showed marked enhancement of immunofluorescent staining in tissue culture. For these reasons we believe that positively staining cells in our ERMs were derived from the RPE (though a ciliary or iris epithelial origin could not be entirely excluded).

SIGNIFICANCE OF RPE CELLS IN ERMS

RPE cells in ERMs may adopt the morphology of macrophages or fibroblasts, while others resemble normal RPE. ${ }^{2-4}$ In this study we identified oval cells, spindle-shaped cells, and cuboidal cells which were positively staining for epithelial markers. Moreover, the staining characteristics in embedded specimens and monolayers were broadly comparable for both prekeratin and keratin, so it is unlikely that the use of additional markers to cytokeratins would demonstrate a further complement of epithelial cells in the ERMs. For these reasons, and bearing in mind our careful use of controls and standards, we consider that cells staining negatively for prekeratin and keratin in the ERMs and monolayers were not of RPE origin.

For the first time, it has been possible specifically to 
identify fibroblast-like cells of epithelial origin in ERMs. Indeed, in one embedded specimen the epithelial component (including fibroblast-like cells) was so prominent as apparently to confirm the 'RPE cell hypothesis' of ERM formation and contraction. ${ }^{2-5}$ However, in a majority of our ERMs (most of which were associated with rhegmatogenous retinal detachment) epithelial cells were either absent or formed only a minor component comprising cells scattered diffusely throughout the specimen. These positively staining but isolated cells might represent wandering macrophages derived from RPE cells ${ }^{2}$ or RPE cells incidentally caught up within developing ERMs following dispersion from Bruch's membrane, showering throughout the retrohyaloid space, and settling on to the retina.

Most fibroblast-like cells in our ERMs were not of epithelial cell origin (as judged by negative staining for prekeratin and keratin). The origin of these nonstaining fibroblasts remains obscure. We have previously shown that they are also unlikely to be of glial origin on the basis of anti-GFAP staining, ${ }^{15}$ neither are they derived from vascular endothelial cells as judged by negative staining with anti-factor VIII related antibody. ${ }^{14}$ Thus, while accepting that biomicroscopic pigmentation of an ERM strongly suggests an RPE cell component, and while conceding that many non-pigmented ERMs also have a RPE cell component, we consider that the fibroblasts or fibroblast-like cells generally held to be responsible for ERM contraction are seldom of RPE origin.

We thank Mr R. J. Cooling, Mr Z. Gregor, and Mr P. K. Leaver who provided many of the surgical specimens, and Mr G. Nunn for ensuring their safe collection. Dr A. H. S. Rahi provided valuable technical guidance, and technical assistance was provided by R. Alexander, J. Prasad, and E. Robins. We are also indebted to Miss Heather Lucas and Mrs Pat Goodwin for secretarial assistance.

Our research has been funded by the TFC Frost Charity Trust, the Wellcome Trust (grant no. 10998/1.5), the Muirhead Settlement, the Moorfields Locally Organised Research Scheme and the Moorficlds Endowment Fund.

\section{References}

1 Smith TR. Pathological findings after retinal surgery. In: Schepens CL, ed. Importance of vitreous body in retinal surgery with special emphasis on reoperations. St Louis: Mosby, 1960: 61-73.

2 Machemer R, Laqua $H$. Pigment epithelium proliferation in retinal detachment (massive periretinal proliferation). Am J Ophthalmol 1975; 80: 1-23.

3 Machemer R. Pathogenesis and classification of massive periretinal proliferation. BrJ Ophthalmol 1978; 62: 737-47.

4 Machemer R, Van Horn D, Aaberg TM. Pigment epithelial proliferation in human retinal detachment with massive periretinal proliferation. Am J Ophthalmol 1978; 85: 181-91.

5 Machemer R, Aaberg TM. Vitreous. Current Ophthalmology Monographs. New York: Grunc and Stratton, 1979: 19-29.
6 Clarkson JG, Green WR, Massof D. A histopathologic review of 168 cases of preretinal membrane. Am J Ophthalmol 1977; 84: $1-17$.

7 Green WR, Kenyon KR, Michels RG, Gilbert HD, De La Cruz Z. Ultrastructure of epiretinal membranes causing macular pucker after retinal reattachment surgery. Trans Ophthalmol Soc UK 1979; 99: 65-77.

8 Kampik A. Kenyon KR. Michels RG, Green WR. De La Cruz Z. Epiretinal and vitreous membranes: Comparative study of 56 cases. Arch Ophthalmol 1981; 99: 1445-54.

9 Harada T, Chauvaud D, Pouliquen Y. An electron microscopic study of the epiretinal membrane of human eyes. Albrecht von Graefes Arch Klin Ophthalmol 1981; 215: 327-39.

10 Hamilton CW, Chandler DB, Klintworth GK, Machemer R. A transmission and scanning electron microscopic study of surgically excised preretinal membrane proliferations in diabetes mellitus. Am J Ophthalmol 1982; 94: 473-88.

11 Trese M, Chandler DB, Machemer R. Macular pucker: II. Ultrastructure. Albrecht von Graefes Arch Klin Ophthalmol 1983; 221: $16-26$.

12 Newsome DA, Rodrigues MM, Machemer R. Human massive perirctinal proliferation. In vitro characteristics of cellular components. Arch Ophthalmol 1981; 99: 873-80.

13 Rodrigues MM. Newsome DA, Machemer R. Further characterization of epiretinal membranes in human massive periretinal proliferation. Curr Eye Res 1981; 6: 311-5.

14 Hiscott PS, Grierson I, Hitchins CA, Rahi AHS, McLeod D. Epiretinal membranes in vitro. Trans Ophthalmol Soc UK 1983; 103: 89-102.

15 Hiscott PS, Grierson I, Trombetta CJ, Rahi AHS, Marshall J, McLeod D. Retinal and cpiretinal glia: an immunohistochemical study. Br J Ophthalmol 1984, in press.

16 Lee LD, Baden HP. A neutral soluble high molecular weight keratin from epidermis. Biochem Biophys Res Comm 1978; 81: 366-73.

17 Sun TT, Tseng SCG, Nelson W, Jarvinen M, Woodcock-Mitchell J, Huang JW. Tissue distribution of keratin antigens: Studies using monoclonal antibodies. ARVO abstracts: supplement to Invest Ophthalmol Visual Sci 1982; 22: 73.

18 Kinoshita S, Friend J, Kiorpes TC, Thoft RA. Keratin-like proteins in corneal and conjunctival epithelium are different. Invest Ophthalmol Visual Sci 1983; 24: 577-81.

19 Mukai K, Rosai J. Applications of immunoperoxidase techniques in surgical pathology. In: Fenoglio CM, Wolff M, eds. Progress in surgical pathology. New York: Masson, 1980: 15-49.

20 Meuller-Jensen K, Machemer R, Azarnia R. Autotransplantation of retinal pigment epithelium in intravitreal diffusion chamber. Am J Ophthalmol 1975; 80: 530-7.

21 Mandelcorn MS, Machemer R, Fineberg E, Hersch SB. Proliferation and metaplasia of intravitreal retinal pigment epithelium cell autotransplants. Am J Ophthalmol 1975; 80: 227-37.

22 Franke WW, Schmid E, Weber K, Osborn M. HeLa cells contain intermediate-sized filaments of the prekeratin type. Exp Cell Res 1979; 118: 95-109.

23 Sieinski W, Dorsett B, Ioachim HL. Identification of prekeratin by immunofluorescence staining in the differential diagnosis of tumours. Hum Pathol 1981; 12: 452-7.

24 Gabbiani G, Kapanci Y, Barazzone P, Franke WW. Immunochemical identification of intermediate-sized filaments in human neoplastic cells. A diagnostic aid for the surgical pathologist. Am J Pathol 1981; 106: 206-16.

25 Altmannsberger M, Weber K, Hölscher A, Schauer A, Osborn M. Antibodics to intermediate filaments as diagnostic tools. Human gastrointestinal carcinomas express prekeratin. Lab Invest 1982; 46: 520-6.

26 Said JW. Immunohistochemical localization of keratin proteins in tumour diagnosis. Hum Pathol 1983; 14: 1017-9.

27 Barr-Nea L, Barishak YR. Behaviour of retinal pigment epithelium in organ culture conditions. Ophthalmic Res 1972; 4: $321-7$ 